\title{
A Review on Implication of Material Management to Project Performance
}

\author{
Zairra Mat Jusoh $^{1, a}$, Narimah Kasim ${ }^{1}$ \\ ${ }^{1}$ Faculty of Technology Management and Business, Universiti Tun Hussein Onn Malaysia, 86400 Batu Pahat, Johor, Malaysia
}

\begin{abstract}
Material management is an important element in project management as materials contribute a major portion to total project cost. It also plays a key role because of the successes of every construction project rely on having proper resources. Thus, it gives implication on project performance. Despite the importance of material management to project performance, there are limited numbers of research available related to this topic. Therefore, the aim of this paper is to identify the effects factors of material management on project performance. Literature from books, journal articles and conferences papers related to this topic are reviewed. In conclusion, exploring the implication of material management towards project performance will benefit construction players in improving the efficiency of material management in order to minimize the impacts on construction projects performance.
\end{abstract}

\section{Introduction}

Construction material is a critical element in the construction project as it contributes a major portion to the cost of projects. The contribution of construction materials may account 50-60\% of the project cost [1]. Due to its role as the major contributor to project cost, managing construction material becomes essential function in the construction project. Therefore, material management is an important element in project management.

Business Roundtable in Modern Management System defined material management as 'the process of planning and controlling all necessary efforts to ensure that the right quality and quantity of materials and equipment are specified in a timely manner, obtained at reasonable cost and available when needed [2, 3]. Some authors interpreted it directly to a concept related to integrated process of materials procurement that are combined under one management function [4, 5]. While others defined it as a combination process of planning, identification, inventory control, receiving and distribution, material handling and storage of materials $[6,7]$. In essence, material management is a planned process combining identification, planning, purchasing, delivery, handling, storing, controlling and distributing with the purpose of ensuring the availability of sufficient quantities, appropriate quality and reasonable cost of construction materials for project's need.

Material management plays important roles in the success of construction projects as highlighted in previous studies $[6,8,9]$. It is important, because the outcome of every construction projects rely on having all proper resources such as materials, labours, plants and equipment delivered to site at appropriate time [10]. Without proper material management in construction projects, construction projects suffer delays, cost overrun,

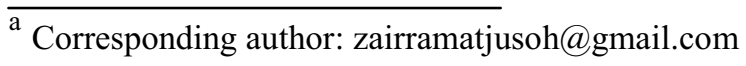

construction waste and low productivity [11-16]. As prior literature reports, among the factors that contribute to poor project performance is due to shortage of materials occur in construction projects $[1,12,17]$. Meaning that, the materials are not available when needed. Thus, existing papers acknowledged that material management has significant effects on project performance.

Despite the importance of material management to project performance. The material management area most often overlooked by the construction players and academicians [18, 19]. This claim seems to be true as only a few papers cover material management topic in local context [20-22]. The existing papers only briefly mentioned that material management influence project performance with limited exploration and empirical study specifically related to relationship of material management on project performance $[1,6,23]$. Moreover, it appears there is lacking of detailed discussion especially about the effect of material management on project performance. The effect of material management needs to be explored to gain better insight and understanding towards improving projects performance through effective material management. Hence, the purpose of this paper is to identify the effect of material management on project performance.

\section{Material Management Processes and Functions}

Material management processes and functions consist of multi-organizations and integrated processes of material definitions, acquisition and field disposition [24]. In this study, these processes and functions are project planning, material take-off, suppliers' enquiry, purchasing, material control, warehousing, expediting and shipping $[2,3]$. 


\subsection{Project Planning}

In material management, planning is the most important parts of the overall material management process $[7,9]$. The planning process comprises the task of identification and determination of required materials, set up and maintain the materials records, determines target inventory levels, delivery frequency including materials logistic planning such as temporary facilities, access roads and storage area [3, 25-27]. Usually, the materials plan are developed based on detailed project design, bills of quantities, procurement plans, resource plan and project schedule [7]. Apparently, the planning process is also integrated with other processes.

\subsection{Material Take-off}

The purpose of material take-off is to obtain an actual total quantity of materials used in the construction projects [4]. Other than quantities of materials, this process is able to ascertain the materials specifications [2]. Clearly, this process is related to identification of what types of material are required and how much the quantities are needed.

\subsection{Supplier Enquiry}

The supplier enquiry process is related to suppliers' evaluation [2]. The criteria need to be considered in evaluating suppliers are price, quality, time of delivery, inventory held by suppliers, and flexibility [5, 9, 28]. However, the priority of these criteria depends on the strategies of each organization [28].

\subsection{Purchasing}

The purpose of purchasing process is to provide the materials at the right time, place, quality and an agreed budget [25]. Basically, this purchasing process starts by receiving the requisition form from the person in charge, followed by purchasing [29]. During this process, the current stockpile, availability of site space and storage areas need to be considered in avoiding material inventory problems [26].

\subsection{Material Control}

The aim of material control is to avoid shortage and surplus of materials occurs at construction sites [7]. This process related to handling, distribution and usage of materials $[30,31]$. Within this task, material control is affected by the degree of the information technology used as the information technology has the ability to optimize this process $[2,24]$.

\subsection{Warehousing}

Primarily, warehousing related to material storage. Storage at the construction site is essential so that the materials already available when needed [18]. However, the stored materials need to be monitored in order to avoid waste, loss and damaged materials due to disorganized stock, improperly sorted, misallocate or deteriorate [25].

\subsection{Material Take-off}

The aim of expediting and shipping process is to ensure selected suppliers deliver the materials, technical specification and equipment to construction site accordingly as per schedule, terms and date specified in the purchase order [3]. This process also related to provide timely information related to materials deliveries [2]. Apparently, this process involves transfer of materials and equipment from suppliers to the construction site including deliveries information when necessary [26].

\section{Influence of Material Management to Project Performance}

As previously mentioned, existing studies on construction project performance have briefly mentioned the effect of material management on project performance. Therefore, reviews of literature summarize that the key criteria of project performance affected due to material management as in Table 1.

A summary is presented in Table 1 for 28 previous papers that mentioned the effect of material management to project performance. Generally, the criteria of project performance are identified both from a positive and negative perspective effects. From positive effects, effective material management has a positive impact on time optimization, cost saving, quality maximization, productivity improvement and waste minimization, [1-3, 32-34]. On the other hand, ineffective material management has negative effects on project performance such as time delay, cost overrun, poor quality, loss of productivity and excessive waste generation $[2,8,11,14$, 35-37]. However, in the context of this paper, the criteria are termed in impartial form namely; time, cost, quality, productivity and waste. Discussion of material management effect on 5 criteria of project performance is as in the following.

\subsection{Time}

Time is defined as a degree that general conditions promoted completions of a project within allocated duration [38]. It is an essence of a construction contract, hence most of the contract have a similar provision about completion time and clearly stated in it [30]. Therefore, it is important for construction project completed on time.

Furthermore, time is widely recognized as minimum performance measured and one of the primary criteria of project success [13, 39-40]. As shown in table 1, total of 24 papers mentioned that material management affect time performance.

The insufficient stock of materials lead to idling time as workers try not to exhaust the stockpile or it is worsened by work stoppage [11, 41]. Due this shortage, materials need to be reordered and causes longer idling 
time. Consequently, the work progress will be delayed. Therefore, the availability and sufficient quantity of materials affect the time performance.

Table 1. Summary of Material Management Affecting Project Performance

\begin{tabular}{|c|c|c|c|c|c|c|}
\hline \multirow[b]{2}{*}{ No. } & \multirow[b]{2}{*}{ Authors } & \multicolumn{5}{|c|}{ Criteria of Project Performance } \\
\hline & & Time & Cost & Quality & Productivity & Waste \\
\hline 1 & $\begin{array}{l}\text { Gulghane \& } \\
\text { Khandve (2015) }\end{array}$ & $\sqrt{ }$ & $\sqrt{ }$ & $\sqrt{ }$ & $\sqrt{ }$ & $\sqrt{ }$ \\
\hline 2 & $\begin{array}{l}\text { Alanjari et al. } \\
(2014)\end{array}$ & $\sqrt{ }$ & $\sqrt{ }$ & & $\sqrt{ }$ & $\sqrt{ }$ \\
\hline 3 & $\begin{array}{l}\text { Barry et al. } \\
(2014)\end{array}$ & $\sqrt{ }$ & $\sqrt{ }$ & $\sqrt{ }$ & & \\
\hline 4 & $\begin{array}{l}\text { Caldas et al. } \\
(2014)\end{array}$ & $\sqrt{ }$ & $\sqrt{ }$ & $\sqrt{ }$ & & \\
\hline 5 & El-Gohary (2014) & & & & $\sqrt{ }$ & \\
\hline 6 & $\begin{array}{l}\text { Hughes \& Thorpe } \\
\text { (2014) }\end{array}$ & $\sqrt{ }$ & $\sqrt{ }$ & & $\sqrt{ }$ & \\
\hline 7 & $\begin{array}{l}\text { Othman et al. } \\
(2014)\end{array}$ & $\sqrt{ }$ & $\sqrt{ }$ & $\sqrt{ }$ & & \\
\hline 8 & Safa et al. (2014) & $\sqrt{ }$ & $\sqrt{ }$ & & & $\sqrt{ }$ \\
\hline 9 & $\begin{array}{l}\text { Abdul Rahman et } \\
\text { al. (2013) }\end{array}$ & $\sqrt{ }$ & $\sqrt{ }$ & & $\sqrt{ }$ & \\
\hline 10 & Aziz (2013) & & $\sqrt{ }$ & & & \\
\hline 11 & $\begin{array}{l}\text { Patil \& Pataskar } \\
\text { (2013) }\end{array}$ & $\sqrt{ }$ & $\sqrt{ }$ & $\sqrt{ }$ & $\sqrt{ }$ & \\
\hline 12 & $\begin{array}{l}\text { Doloi et al. } \\
\text { (2012) }\end{array}$ & $\sqrt{ }$ & & & & \\
\hline 13 & Meng (2012) & $\sqrt{ }$ & $\sqrt{ }$ & & & \\
\hline 14 & Nagapan (2012) & & & & & $\sqrt{ }$ \\
\hline 15 & Sardroud (2012) & $\sqrt{ }$ & $\sqrt{ }$ & & $\sqrt{ }$ & \\
\hline 16 & $\begin{array}{l}\text { Ameh \& Osegbo } \\
(2011)\end{array}$ & $\sqrt{ }$ & & & $\sqrt{ }$ & \\
\hline 17 & $\begin{array}{l}\text { Haseeb et al. } \\
(2011)\end{array}$ & $\sqrt{ }$ & & & & \\
\hline 18 & Ren et al. (2011) & $\sqrt{ }$ & $\sqrt{ }$ & & $\sqrt{ }$ & $\sqrt{ }$ \\
\hline 19 & $\begin{array}{l}\text { Kasim \& Ern } \\
(2010)\end{array}$ & $\sqrt{ }$ & $\sqrt{ }$ & $\sqrt{ }$ & & \\
\hline 20 & $\begin{array}{l}\text { Nwachukwa \& } \\
\text { Emoh (2010) }\end{array}$ & $\sqrt{ }$ & $\sqrt{ }$ & & & \\
\hline 21 & $\begin{array}{l}\text { Wan \& } \\
\text { Kumaraswamy } \\
(2009)\end{array}$ & & & & & $\sqrt{ }$ \\
\hline 22 & $\begin{array}{l}\text { Kazaz et al. } \\
(2008)\end{array}$ & $\sqrt{ }$ & $\sqrt{ }$ & & $\sqrt{ }$ & \\
\hline 23 & $\begin{array}{l}\text { Enhassi et al. } \\
(2007)\end{array}$ & $\sqrt{ }$ & & $\sqrt{ }$ & $\sqrt{ }$ & $\sqrt{ }$ \\
\hline 24 & $\begin{array}{l}\text { Caldas et al. } \\
(2006)\end{array}$ & $\sqrt{ }$ & $\sqrt{ }$ & & & \\
\hline 25 & $\begin{array}{l}\text { Novan \& } \\
\text { Berkhovich } \\
\text { (2006) }\end{array}$ & $\sqrt{ }$ & $\sqrt{ }$ & & & $\sqrt{ }$ \\
\hline 26 & $\begin{array}{l}\text { Kasim, Anumba } \\
\text { \& Dainty }\end{array}$ & $\sqrt{ }$ & $\sqrt{ }$ & $\sqrt{ }$ & $\sqrt{ }$ & \\
\hline 27 & Song et al. (2005) & $\sqrt{ }$ & $\sqrt{ }$ & & $\sqrt{ }$ & \\
\hline \multirow[t]{2}{*}{28} & $\begin{array}{l}\text { Thomas et al. } \\
(2005)\end{array}$ & $\sqrt{ }$ & $\sqrt{ }$ & & $\sqrt{ }$ & \\
\hline & Total Frequency & 24 & 21 & 8 & 14 & 8 \\
\hline
\end{tabular}

Material inventory affects the construction time. The systematic inventory control and documentation reduce time consumption for labour to retrieve materials [41]. Other effects are on time delivery of material increases work progress, used appropriate quality material speed up finishing time, on time material procurement reduces idling time and reasonable changes reduces extra time for adjustment of resources [35-37, 42].

\subsection{Cost}

Cost of construction project is defined as a price to a client including consultant's fees, main contractors' and trade contractors' charges including their overhead and profit [43]. Cost is one of the major consideration in entire cycle of construction projects. Unfortunately, majority of the projects failed to achieve project completion according to the contract cost [44].

Table 1 shows 21 existing papers stated that material management has effect on cost performance. With effective material management in construction projects, it is able to reduce overall cost of material [45]. For example, in purchasing process, discounts and bulk order may be economical as it reduced the transportation and ordering cost $[29,46]$. It has been estimated that a saving of $2 \%$ material cost possibly will increase profits by $14.6 \%$ [7]. Thus, by minimizing the procurement cost of materials, the higher chances for reducing the overall project cost and concurrently increasing company profit.

However, the reasonable time needs to consider as if the materials ordered too early, it may affect the company capital, interest charges and storage charges [45]. The total quantity required also vital to be considered as the main reason of cost variance in construction projects is due to overstocked materials on site [6]. Because of overstocked materials, organizations need to spend extra expenses on cost for labour wages and transportation charges to move out the materials from site.

Lack of standard or poor quality control in material management contributes to increase of construction cost. This is because the chances to loss material during handling and implementation stages is higher and it requires a material replacement [46]. For instance, the materials with poor quality will damage due to lack of durability, strength and density [36].

The planning and procurement is claimed as an equally important process that control total project cost [6]. However, material control and expediting also important as the former process is to avoid shortage and surplus of materials occurred on site. While the later process ensures the material being delivered in a timely manner by suppliers [7, 46]. In sum, all mentioned processes are important to reduce the escalation of construction cost.

\subsection{Quality}

Quality is defined as the specific characteristic, features or nature of products, execution or installations of a task on construction project as stipulated in the contract document [47]. However, the term quality has sometimes become a problem as it is a subjective matter and understood differently by different people and organizations [39, 48]. Therefore, it is important to 
consultant be able to identify clients requirements and specify clearly in contract document.

As shown in Table 1, 8 papers mentioned that material management affects quality performance. Availability of resources such as materials and equipment as planned during project duration is one of the factors contributing to quality performance [49]. The available equipment also needs to be in good condition and in sufficient quantity. Without the proper and sufficient equipment, it will jeopardize the satisfactory quality of work done [50]. Similarly, the materials itself also need to be in appropriate quality according to the specification $[11,42]$. Using the appropriate quality of materials can lead to the satisfactory quality of work, subsequently will be accepted by consultant [36]. In sum, the available resources must be in accordance to the specification, sufficient quantity and functional.

\subsection{Productivity}

Productivity can be interpreted in many ways. In context of construction, productivity is related to labour productivity. It constitutes units of work placed or produced per staff [15]. The productivity is measured in terms of unit completely accomplished during given period and the related costs in terms of man-hours or money [51]. In short, productivity can be defined as ratio of earned either completed units or associated cost to actual hours [15].

A study on factors affecting Australian construction productivity reported that lack of materials is a primary factors that had a moderate to strong effect on productivity [50]. Similarly, studies conducted in Indonesia and Thailand also revealed that lack of materials affect construction productivity $[52,53]$. More importantly, it has been accumulated that disruptions in material management resulted in $9 \%$ of loss of labour productivity [54].

Material storage also had a significant impact on labour productivity. For example, inappropriate storage location increases unproductive inputs. This occurs as the workers need longer time and effort to retrieve materials. Due to this, it only wasting workers' energy and may end up physically fatigue [55]. On the contrary, with appropriate site storage, workers energy can be productively used to perform task under progress.

This situation also similar with the efficient site layout for material movement. With efficient movement of materials, it increases productivity whilst reduces material travel time [19, 32]. The accessibility of site and unconfined working space also affects workers' productivity [55]. Besides, the availability of material and equipment motivated workers to improve work productivity [10]. Indeed, these studies demonstrated the interrelationship between the material management and productivity performance in construction projects as 14 papers mentioned it (Table 1).

\subsection{Waste}

Construction waste refers to any material except earth material that needs to be moved out from the site due to damage, excess either non-use or cannot be used due to non-compliance with specification and surplus or debris by-product of construction process [56]. In simple word, waste is a product or material that is unwanted and required to transport out from site [11].

Inappropriate material storage contributes to waste generation in Singaporean construction sites [56]. Likewise, previous studies in Malaysia also revealed that poor material storage and poor material handling are the highest cause to waste generation in local construction industry $[11,57]$. The above mentioned study supported 8 prior papers about the effect of material management to waste performance.

Strategies for waste minimization are stock control for minimization of over or duplicate ordering, good practices of material handling, systematic inventory process and proper material storage $[6,18,58]$. Hence, the efficient material management practice throughout entire construction process will minimize the waste generation [1]. Additionally, minimization of material wastage in construction project is important to avoid loss of profit for the contractors $[18,25,56]$. Evidently, it has been revealed that $2.5 \%$ of total budget can be saved due to implementation of waste minimization strategies [59].

\section{Conclusion}

This paper had identified the effect of material management to 5 criteria of project performance. In conclusion:-

i) The availability and sufficient materials and equipment have effect on time, quality, productivity and performance.

ii) Appropriate quality material has effect on time, cost and quality performance.

iii) On time and reasonable time of material procurement have effect on time and cost performance.

iv) Efficient inventory system and documentation have effect on time and waste performance.

v) Reasonable changes has effect on time performance.

vi) On time delivery has effect on time performance.

vii) Minimizing procurement cost has effect on cost performance.

viii) Appropriate site storage has effect on productivity and waste performance.

ix) Efficient site layout has effect on productivity performance.

x) Easy site access has effect on productivity performance.

xi) Unconfined working space has effect on productivity performance.

xii) Efficient material controlling has effect on waste performance.

xiii) Appropriate handling has effect on waste performance.

Further examination of these effects of material management to project performance will be conducted with practitioners to confirm the severity of each effect on criteria of project performance. 


\section{Acknowledgement}

The authors would like to express the profound gratitude to their supervisor for her invaluable guidance, encouragement and supervision. The gratitude also to UTHM as this paper was partly sponsored by Centre for Graduate Studies UTHM.

\section{References}

1. M. Safa, A. Shahi, C.T. Haas, K.W. Hipel, Automation in Construction 48, 64-73 (2004)

2. L.C. Bell, G. Stukhart, Journal of Construction Engineering and Management 112, 14-21 (1986)

3. C.H. Caldas, C.L. Menches, P.M. Reyes, L. Navarro, D.M. Vargas, Practice Periodical on Structural Design and Construction 20, 1-8 (2014)

4. K.K Chitkara, Construction Project Management: Planning, Scheduling and Controlling. (1998)

5. W.C. Benton, L. McHenry, Construction Purchasing \& Supply Chain Management. (2010)

6. A.A. Gulghane, P.V. Khandve, International Journal of Engineering Research and Application 5, 59-64 (2015)

7. Z. Ren, C.J. Anumba, J. Tah, Advanced Engineering Informatics 25, 198-207 (2011)

8. J.M. Sardroud, Scientia Iranica 19, 381-392 (2012)

9. J.H. Berka, W.D. Conn, AACE International Transactions 1994, SI2-1(1994)

10. W. Barry, F. Leite, W.J. O’Brien, In Construction Research Congress 2014, 2296 2305 (2014)

11. S. Nagapan, I. Abdul Rahman, A. Asmi, International Journal of Advances in Applied Sciences 1,1-10 (2012)

12. H. Doloi, A. Sawhney, K.C Iyer, S. Rentala, International Journal of Project Management, 30, 479-489 (2012)

13. X. Meng, International Journal of Project Management 30, 188-198 (2012)

14. I. Abdul Rahman, A.H. Memon, A. Azis, A. Asmi, N.H Abdullah, Research Journal of Applied Sciences, Engineering and Technology 5, 1963-1972 (2013)

15. K.M. El-Gohary, R.F. Aziz, Journal of Management in Engineering 30, 1-9 (2014)

16. Z. Shehu, G.D. Holt, I.R. Endut, A. Akintoye, Built Environment Project and Asset Management 5, 52-68 (2015)

17. R.A. Rivas, J.D. Borcherding, V. González, L.F. Alarcón, Journal of Construction Engineering and Management 137, 312-320 (2010)

18. D.U. Kini, Journal of Management in Engineering 15, 30-34 (1999)

19. S. Donyavi, R. Flanagan, R. Proceedings of the 25th Annual ARCOM Conference, 11-20 (2009)
20. H. Abdul Rahman, M.N. Alidrisyi, Construction Management and Economics 12, 413-422 (1994)

21. N. Kasim, P.A.S. Ern, Int. Journal of Computer and Communication Technology 2, 1-10 (2010)

22. N. Kasim, KICEM Journal of Construction Engineering and Project Management, 31-36 (2011)

23. S. Meeampol, S.O. Ogunlan, Journal of Financial Management of property and Construction 11, 3-20 (2006)

24. W.E. Back, L.C. Bell, Cost EngineeringMorgantown 38, 13-17 (1996)

25. N. Kasim, C.J. Anumba, A.R.J. Dainty, Proceedings Twenty First Annual Association of Researchers in Construction Management (ARCOM) Conference, 793-802 (2005)

26. H. Said, K. El-Rayes, Construction Research Congress 2012, 1580-1589 (2012)

27. C.H. Caldas, D.G. Torrent, C.T. Haas, Journal of Construction Engineering and Management 132, 741-749 (2006)

28. G. Ali, Advances in Management 7, 17 (2014)

29. T.P. Madhavi, S.V. Mathew, R. Sasidharan, International Journal of Research in Engineering and Technology, 400-403 (2013)

30. B. Cooke, P. Williams, Construction Planning, Programming and Control, (2009)

31. W.R. Mincks, H. Johnston, Construction Jobsite Management, (2011)

32. P. Alanjari, S. Razavialavi, S. AbouRizk, Automation in Construction 40, 1-8 (2014)

33. S.K. Wan, M.M. Kumaraswamy, Engineering, Construction and Architectural Management 16, 208-223 (2009)

34. H.R. Thomas, D.R. Riley, J.I Messner, Journal of Construction Engineering and Management 131, 808-815 (2005)

35. A. Kazaz, E. Manisali, S. Ulubeyli, Journal of Civil Engineering and Management 14, 95-106 (2008)

36. A. Enshassi, S. Mohamed, Z. Abu Mustafa, P.E Mayer, Journal of Civil Engineering and Management 13, 245-254 (2007)

37. R. Navon, O. Berkovich, Construction Management and Economics 24, 635-646 (2006)

38. A.P.C. Chan, D. Scott, E.W.M. Lam, Journal of Management in Engineering 18, 120-128 (2002)

39. A.S. Ali, I. Rahmat, Journal of Retail \& Leisure Property 9, 25-35 (2010)

40. H.S. Cha, C.K. Kim, KSCE Journal of Civil Engineering 15, 1319-1328 (2011)

41. M.R. Abdul Kadir, W.P. Lee, M.S. Jaafar, S.M. Sapuan, A. Ali, Structural Survey 23, 42-54 (2005)

42. C.C. Nwachukwu, F.I. Emoh, Interdisciplinary Journal of Contemporary Research in Business 2, 90-105 (2010)

43. D. Towey, Cost Management of Construction Projects (2013) 
44. N.J. Smith, T. Merna, P. Jobling, Managing Risk in Construction Projects (2014)

45. A.R. Patil, S.V. Pataskar, International Journal of Engineering and Innovation Technology 3, 96-100 (2013)

46. R.F. Aziz, Alexandria Engineering Journal 52, 51-66 (2013)

47. W.J. Del Pico, Project Control-Integrating Cost and Schedule in Construction (2013)

48. A.A. Kwakye, Construction Project Administration In Practice (1997)

49. K.N. Jha, K.C. Iyer, Total Quality Management \& Business Excellence 17, 1155-1170 (2006)

50. R. Hughes, D. Thorpe, Construction Innovation: Information, Process, Management 14, 210-228 (2014)

51. R.F. Cox, R.R. Issa, D. Ahrens, Journal of construction engineering and management 129 , 142-151 (2003)

52. P.F. Kaming, P.O. Olomolaiye, G.D. Holt, F.C. Harris, International Journal of Project Management 15, 21-30 (1997)

53. A. Makulsawatudom, M. Emsley, 17th Annual ARCOM Conference, 281-290 (2001)

54. H.R. Thomas, D.R. Riley, V.E. Sanvido, Journal of Construction Engineering and Management 125, 39-46 (1999)

55. A.M. Jarkas, C.G. Bitar, Journal of Construction Engineering and Management 138, 811-820 (2011)

56. L.L. Ekanayake, G. Ofori, Building and Environment 39, 851-861 (2004)

57. S.H. Hassan, N. Ahzahar, M.A. Fauzi, J. Eman, Procedia - Social and Behavioral Sciences 42, 175-181 (2012)

58. R.A. Begum, C. Siwar, J.J. Pereira, A.H. Jaafar, Resources, Conservation and Recycling 51, 190-202 (2007)

59. R.A. Begum, C. Siwar, J.J. Pereira, A.H. Jaafar Resources, Conservation and Recycling 48, 8698 (2006) 